\title{
Antidiabetic activity of musa acuminata colla fruit peel (MACFP) ethanol extract in glucose-induced diabetic rats
}

\author{
Erza Genatrika*, Visda Nila Happy Laksari, and Tjiptasurasa Tjiptasurasa \\ Universitas Muhammadiyah Purwokerto, Faculty of Pharmacy, Jl. Raya Dukuh Waluh PO Box 202, Purwokerto, Indonesia
}

\begin{abstract}
Diabetes mellitus is a metabolic disorder disease characterized by increased blood glucose levels due to impaired insulin secretion or increased insulin resistance. The study was performed to investigate the blood glucose lowering effect of Musa acuminata Colla fruit peel (MACFP) ethanol extract in experimentally induced diabetic rats. 25 rats were divided into five groups, i.e negative control group ( $0.5 \% \mathrm{NaCMC})$, positive control group (glibenclamide), and treatment group of MACFP ethanol extract with dose 250,375 , and $500 \mathrm{mg} / \mathrm{kg}$ body weight $(\mathrm{mg} / \mathrm{kg} \mathrm{BW})$. The blood sample was taken from the lateral vein of the tail, and then blood glucose level was observed on $0,30,60,90$, and 120 minutes. The results provide information that MACFP ethanol extract with dose 250,375 , and $500 \mathrm{mg} / \mathrm{kg} \mathrm{BW}$ have the same effect with a positive control (glibenclamide) in lowering blood glucose level on diabetic rats ( $p>0,05$ ). MACFP ethanol extract with dose $500 \mathrm{mg} / \mathrm{kg}$ BW had the highest percentage of decrease in blood glucose level (42,62\%), followed by doses $375 \mathrm{mg} / \mathrm{kg} \mathrm{BW}(37,26 \%)$ and 250 $\mathrm{mg} / \mathrm{kg} \mathrm{BW}(24,12 \%)$.
\end{abstract}

\section{Introduction}

Diabetes Mellitus (DM) is a group of metabolic disorder diseases in which blood sugar levels are abnormally high over a prolonged period, that occur due to abnormalities of insulin secretion, insulin work or both [1]. According to the World Health Organization (WHO) in 2016, DM patients in the world's increased from 108 million (1980) to 422 million (2014). International Diabetes Federation (IDF) estimates DM patients in the worlds at 2040 to 642 million. Furthermore, according to the journal of Diabetes Care, DM patients in Indonesia in 2030 is estimated go up from 8.4 million in 2000 to 21.3 million in 2030 [2].

The increasing number of DM patients causes increased use of antidiabetic drugs. Currently, antidiabetic agents from the plant have been widely developed towards phytopharmaca. One of them that will be developed is a plant of Ambon banana (Musa acuminata Colla). The part of the plant that is used is the peel of the fruit.

According to Someya (2002), banana fruit peel has higher antioxidant activity than the pulp. This is because the antioxidant compound was more abundant in peel $(158 \mathrm{mg} / 100 \mathrm{~g}$ dry wt.) than in pulp $(29.6 \mathrm{mg} / 100 \mathrm{~g}$ dry wt.) [3].

The antioxidant compound contained in the Musa acuminata Colla fruit peel is flavonoid. Flavonoid has an important role in controlling blood glucose level and prevent complications of diabetes mellitus [4,5]. The results of previous research, water extract of banana fruit

\footnotetext{
*Corresponding author: erzagenatrika@gmail.com
}

peel of Ambon with a dose of $400 \mathrm{mg} / \mathrm{kg} \mathrm{BW}$ has antidiabetic effect in alloxan induced white rats [6].

Scientific data about the banana fruit peel of Ambon as antidiabetic have not much found, so it is still needed research on the banana fruit peel of Ambon with different methods. This is an attempt to prove that the banana fruit peel of Ambon will be developed as an antidiabetic agent.

\section{Materials and methods}

\subsection{Materials}

Musa acuminata Colla, 25 male white rats of Wistar strain (aged 2 to 3 months weighing 150 to $200 \mathrm{~g}$ ), glucose, $\mathrm{NaCMC}$, ethanol, glibenclamide, glucometer, pellet, and water.

\subsection{Licensing of ethical clearance}

This research using test animals is required to permit ethical clearance to ensure that this test did not use methods that violate animal testing regulations. This permission is submitted to the ethics commission in Faculty of Medicine, University of Jenderal Soedirman.

\subsection{Determination of Plants}

Plants were obtained on Banjaranyar Village, Sokaraja, Banyumas are determined to find out the true identity of 
the plant being tested. The determination was done at the Laboratory of Plant Taxonomy, Faculty of Biology, University of Jenderal Soedirman.

\subsection{Extract Preparation}

The banana fruit peel was dried for 2 weeks, then the dried samples are made into powder. 500 grams of simplicia powder soaked with $96 \%$ ethanol solvent as much as 3 liters for 3 days with occasional stirring, then filtered with filter paper. The filtrate is collected, then the residue was re-macerated with $96 \%$ ethanol solvent up to 3 times. The overall filtrate obtained was evaporated using an evaporator, then evaporated using a water bath at a temperature of $60^{\circ \circ} \mathrm{C}$ to obtain a concentrated extract [7].

\subsection{Compound Identification}

\subsubsection{Flavonoid Test (Shinoda Method)}

The extract was took $2 \mathrm{~g}$ and added enough magnesium powder and 10 drops of $5 \mathrm{M}$ hydrochloric acid. The presence of flavonoids was characterized by the formation of reddish black [8].

\subsection{Antidiabetic Test}

25 male white rats have fasted for 12-18 hours, subsequently were divided into 5 groups :

Group 1 : Glibenclamide in 0,5\% $\mathrm{NaCMC}$ with dose of $0,6 \mathrm{mg} / \mathrm{kg} \mathrm{BW}$ as a positive control (PC)

Group 2: $\quad 0,5 \% \mathrm{NaCMC}$ as a negative control (NC)

Group 3: $\quad$ MACFP ethanol extract with a dose of 250 $\mathrm{mg} / \mathrm{kg} \mathrm{BW}$

Group 4: $\quad$ MACFP ethanol extract with a dose of 375 $\mathrm{mg} / \mathrm{kg} \mathrm{BW}$

Group 5 : MACFP ethanol extract with a dose of 500 $\mathrm{mg} / \mathrm{kg} \mathrm{BW}$

All groups after 30-minute was getting treatment orally, they were given glucose orally with a dose of $6,75 \mathrm{~g} / \mathrm{kg} \mathrm{BW}$, this was based on preliminary experiments $[9,10]$. The blood was took from a vein lateral at minute $0 ; 30 ; 60 ; 90 ; 120$ that was calculated after administration of glucose orally and measured blood glucose levels using a glucometer.

\section{Data Analysis}

The results of this study will be analyzed descriptively and statistically. Descriptive analysis was used on the data of compound identification. The data of blood glucose levels calculated the value of $\mathrm{AUC}_{0-120}$ and \%DBGL (Percentage Decrease of Blood Glucose Level) from each group. Then, the value of $\mathrm{AUC}_{0-120}$ was analyzed statistically using one way ANOVA if it fulfilled normality and homogeneity of the data requirement.

\section{Result and discussion}

\subsection{MACFP Extraction}

Extracts of MACFP were obtained through maceration process using $96 \%$ ethanol solvent due to its capability to dissolve almost all substances including polar, semipolar, and nonpolar substances [11]. The obtained dense extract was $22,84 \mathrm{~g}$ with $4,568 \%$ of rendemen percentage.

\subsection{Compounds Identification}

Compounds identification was to determine the presence of flavonoid compound in the extract of MAFCP, it can be seen in table 1 . This was because that compound was alleged to be effective in decreasing of blood glucose level.

Table 1. Compounds Identification Result.

\begin{tabular}{|c|c|c|}
\hline Compounds & Reactors & Results \\
\hline Flavonoid & $\mathrm{Mg}+$ dense $\mathrm{HCl}$ & + \\
\hline
\end{tabular}

Notes : $(-)=$ undetected, $(+)=$ detected

\subsection{Antidiabetic Test}

Table 2. The Average of Blood Glucose Levels.

\begin{tabular}{cccccc}
\hline \multirow{2}{*}{ roup } & \multicolumn{5}{c}{ The average of blood glucose level (mg/d) \pm SD } \\
\cline { 2 - 5 } & 0 & 30 & 60 & 90 & 120 \\
\hline I & $92 \pm 14,4$ & $157,4 \pm 20,8$ & $139,8 \pm 18,3$ & $113 \pm 5,4$ & $77,2 \pm 15,6$ \\
II & $82,4 \pm 16,4$ & $285,8 \pm 73,3$ & $256,8 \pm 71,7$ & $227,2 \pm 57,9$ & $205,0 \pm 60,4$ \\
III & $103,6 \pm 22,6$ & $238,6 \pm 14,3$ & $185,2 \pm 14,4$ & $149,6 \pm 9,2$ & $135,8 \pm 13,7$ \\
IV & $109,4 \pm 17,0$ & $190,6 \pm 13,7$ & $151,4 \pm 12,7$ & $122,4 \pm 14,8$ & $108 \pm 11,7$ \\
V & $78 \pm 17,1$ & $183,4 \pm 21,2$ & $148,8 \pm 24,7$ & $108 \pm 9,3$ & $89,8 \pm 18,1$ \\
\hline
\end{tabular}

Notes :

I : Positive control (glibenclamide)

II : Negative control (NaCMC)

III : MACFP ethanol extract $(250 \mathrm{mg} / \mathrm{kg} \mathrm{BW})$

IV: MACFP ethanol extract $(375 \mathrm{mg} / \mathrm{kg} \mathrm{BW})$

$\mathrm{V}$ : MACFP ethanol extract (500mg/kg BW) 
Measurement of blood glucose levels is started at minutes 0 up to 120 minutes every 30 minutes. Widyaningsih et al. (2004) reported normal blood glucose levels ranging from $50-135 \mathrm{mg} / \mathrm{dl}$ [12]. Based on table 2, group II (negative control) showed that blood glucose levels were abnormal every time measurement. Furthermore, data of blood glucose levels have calculated the value of Area Under Curve (AUC) from 0 up to 120 minutes $\left(\mathrm{AUC}_{0-120}\right)$, it can be seen in table 3 .

The value of $\mathrm{AUC}_{0-120}$ was used as an illustration of antidiabetic effects of MACFP ethanol extract. $\mathrm{AUC}_{0-120}$ value is getting smaller, so the effect of antidiabetic is getting bigger. Negative control group has the biggest $\mathrm{AUC}_{0-120}$ value and the positive control group has the lowest $\mathrm{AUC}_{0-120}$ value. Treatment group with a dose of $500 \mathrm{mg} / \mathrm{kg} \mathrm{BW}$ has the lowest $\mathrm{AUC}_{0-120}$ value, so the effect of antidiabetic is bigger than a dose of $250 \mathrm{mg} / \mathrm{kg}$ $\mathrm{BW}$ and $375 \mathrm{mg} / \mathrm{kg} \mathrm{BW}$ (table 3).

$\mathrm{AUC}_{0-120}$ values were analyzed statistically. An analysis was done to the value of $\mathrm{AUC}_{0-120}$ using one way ANOVA because it had been fulfilled normality and homogeneity of data requirement $(p>0,05)$. Based on the analysis result, it was discovered that there was a significantly different in each treatments groups, positive and negative control $(\mathrm{p}<0,05)$. Moreover, an analysis using LSD test was conducted to find out which groups were significantly different (the result can be seen in table 4).

Table 3. The Value of $\mathrm{AUC}_{0-120}$

\begin{tabular}{|c|c|c|c|c|c|}
\hline \multirow{2}{*}{ Group } & \multicolumn{5}{|c|}{ AUC $0-120$} \\
\cline { 2 - 6 } & $0-30$ & $30-60$ & $60-90$ & $90-120$ & $\begin{array}{c}\text { Total } \\
\text { AUC }\end{array}$ \\
\hline I & 3741 & 4458 & 3792 & 2853 & 14844 \\
\hline II & 5523 & 8139 & 7260 & 6483 & 27405 \\
\hline III & 5133 & 6357 & 5022 & 4281 & 20793 \\
\hline IV & 4500 & 5130 & 4107 & 3456 & 17193 \\
\hline V & 3921 & 4983 & 3852 & 2967 & 15723 \\
\hline
\end{tabular}

Notes :

I : Positive control (glibenclamide)

II : Negative control ( $\mathrm{NaCMC})$

III : MACFP ethanol extract $(250 \mathrm{mg} / \mathrm{kg} \mathrm{BW})$

IV: MACFP ethanol extract $(375 \mathrm{mg} / \mathrm{kg} \mathrm{BW})$

$\mathrm{V}$ : MACFP ethanol extract $(500 \mathrm{mg} / \mathrm{kg} \mathrm{BW})$

Then, $\mathrm{AUC}_{0-120}$ value of each treatment group were calculated percentage of DBGL (Decrease Blood Glucose Levels), it can be seen in table 5. \%BDGL is the difference of $\mathrm{AUC}_{0-120}$ value from negative control with $\mathrm{AUC}_{0-120}$ value from treatment group, then the result is divided by negative control AUC0-120 value, then multiplied by $100 \%$ [13]. $\mathrm{AUC}_{0-120}$ value is inversely correlated with \% DBGL value, so if $\mathrm{AUC}_{0-120}$ value is getting smaller, then the value of \% DBGL is getting greater.
Table 4. LSD Analysis Result.

\begin{tabular}{|c|c|c|}
\hline $\begin{array}{c}\text { Between- } \\
\text { group }\end{array}$ & p-Value & Statistics Test Results \\
\hline I-II & 0,000 & Significantly different \\
\hline I-III & 0,218 & Not significantly different \\
\hline I-IV & 0,294 & Not significantly different \\
\hline I-V & 0,369 & Not significantly different \\
\hline II-III & 0,000 & Significantly different \\
\hline II-IV & 0,000 & Significantly different \\
\hline II-V & 0,001 & Significantly different \\
\hline III-IV & 0,843 & Not significantly different \\
\hline III-V & 0,794 & Not significantly different \\
\hline IV-V & 0,938 & Not significantly different \\
\hline
\end{tabular}

Notes :

I : Positive control (glibenclamide)

II : Negative control (NaCMC)

III : MACFP ethanol extract $(250 \mathrm{mg} / \mathrm{kg} \mathrm{BW})$

IV: MACFP ethanol extract $(375 \mathrm{mg} / \mathrm{kg} \mathrm{BW})$

$\mathrm{V}$ : MACFP ethanol extract $(500 \mathrm{mg} / \mathrm{kg} \mathrm{BW})$

Table 5. Percentage of DBGL

\begin{tabular}{|c|c|}
\hline Group & $\%$ DBGL \\
\hline Positive control (glibenclamide) & $45,83 \%$ \\
\hline MACFP ethanol extract $(250 \mathrm{mg} / \mathrm{kg} \mathrm{BW})$ & $24,12 \%$ \\
\hline MACFP ethanol extract $(375 \mathrm{mg} / \mathrm{kg} \mathrm{BW})$ & $37,26 \%$ \\
\hline MACFP ethanol extract $(500 \mathrm{mg} / \mathrm{kg} \mathrm{BW})$ & $42,62 \%$ \\
\hline
\end{tabular}

Based on table 4, it can be inferred that MACFP ethanol extract has the same effect on the positive control to reduce the blood glucose levels $(p>0,05)$. And then, based on table 5 showed that MACFP ethanol extract with dose $500 \mathrm{mg} / \mathrm{kg} \mathrm{BW}$ had the highest ability to reduce the blood glucose levels as much as $42,62 \%$, followed by doses $375 \mathrm{mg} / \mathrm{kg} \mathrm{BW}(37,26 \%)$ and 250 $\mathrm{mg} / \mathrm{kg} \mathrm{BW}(24,12 \%)$. This is because MACFP ethanol extract has flavonoid compound. Flavonoid is an antioxidant that can play a role in protecting cells of $\beta$ pancreatic from damage caused by free radicals (Widowati, 1997) [14]. Effendi (2008) states that flavonoid can stimulate the pancreas to produce more insulin, therefore blood glucose levels in diabetic male white rats can be reduced [15].

\section{Conclusion}

MACFP ethanol extract with dose $250 \mathrm{mg} / \mathrm{kg} \mathrm{BW}, 375$ $\mathrm{mg} / \mathrm{kg} \mathrm{BW}$ and $500 \mathrm{mg} / \mathrm{kg} \mathrm{BW}$ has the same effect with positive control in lowering blood glucose on male white rats $(\mathrm{p}>0,05)$.

\section{References}

1. Gustaviani, R., Diagnosis and Classification of Diabetes Mellitus, Internal Medicine Textbook, Publisher of Medicine Faculty of Indonesia University, Jakarta (2006)

2. Wild Sarah, Roglic Gojka, Green Anders, Sicree 
Richard, \& Hilary, K., Global Prevalence of Diabetes: Estimates for the year 2000 and projection for 2030, Diabetes Care, 27(5),10471053, https://doi.org/10.2337/diacare.27.5.1047 (2004)

3. Someya, S., Yoshiki, Y., Okubo, K., Antioxidant compounds from bananas (Musa Cavendish), Food Chemistry, 79, 3, November 2002, Pages 351-354 (2002)

4. Abdelmoaty, M. A., Ibrahim, M. A., Ahmed, N. S., \& Abdelaziz, M. A., Confirmatory Studies on The Antioxidant and Antidiabetic Effect of Quercetin in Rats, Indian Journal of Clinical Biochemistry, 25(2), 188-192. https://doi.org/10.1007/s12291010-0034-x (2010)

5. Jack, Synthesis of Antidiabetic Flavonoids and Their Derivative, Medical Research, Page 180 (2012)

6. Indrawati, S., Yuliet, \& Ihwan, Antidiabetic Effect of Musa paradisiaca L. Fruit Peel Water Extract in Mus musculus Hyperglycemia Model, Journal of Pharmacy, 2 (1), 133-140 (2015)

7. Ministry of Health, Galenic Preparation, Ministry of Health of Republic Indonesia, Directorate of General of Drug and Food Control, Jakarta (1986)

8. Harbone, J.B., Phytochemical Methods: A Guide to Modern Techniques of Plants Analysis, Fakenham Press Limited, New York (1973)

9. Rahayuningsih, N., and Amalia, S., Antidiabetic Activity of Pilea trinervia Wight. leaves ethanol extract in Swiss Webster mice, Health Journal of Bakti Tunas Husada, 12 (1), 1-9 (2014)

10. Mokuna, N.,Pitopang, R., and Yuliet, Antidiabetic Effect of Garcinia rostrata Hassk.ex Hook.f Radix on mice (Mus musculus) by using glucose tolerance and alloxan methods, Biocelebes, 8 (2), 37-47 (2014)

11. Arifin, H., Anggraini, N., Handayani, D., and Rasyid, R, Standardization of Eugenia Cumini Merr Leaf Ethanol Extract, Journal of Pharmaceutical Technology Science, 11 (2) (2006)

12. Widyaningsih, W., Ruknaeni, E., Ratnawati, N., Hypoglycemic Effects of Ethanol Extract of Aloe Vera Leaf (Aloe Barbandensis Mill.) In Rats Male of Sprague-Dawley strain, Pharmacon, 5, No 2, page 65-69 (2004)

13. Sujono, T.A., and Wahyuni, A.S., The Effect of Aloe vera L. Leave Decocta Toward Blood Glucose Level in Glucose-Induced Diabetic Rabbit, Journal of Science and Technology, 6 No 1, 2005: 26-34 (2005)

14. Widowati, L., Dzulkamain, Sa'rom, Medicinal Plants for Diabetes Mellitus, Cermin Dunia Kedokteran, No 116 (1997)

15. Effendi, R., Control of Blood Glucose Levels By Green Tea and Tea of Mulberry Leaf in Diabetic Rats, Thesis, Graduate School of Bogor Agricultural University, Bogor (2008) 